\title{
わが国およで中国における「土术のの 語義の歴史的変遷に関する研究
}

藤田龍之*

現在われわれが使っている「土木」という言葉の語義について,これまで種々の報告 があるが, その語義の歴史的な変遷については, まだ充分に明らかにされてはいない. この報告では中国および日本の文献に現れる「土木」という言葉の語義について,『史記』, 『漢書』をはじめとする二十四正史, 諸橋䡴治著『大漢和辞典』, あるいはわが国の日記, 随筆, 歴史書などにより調へ, その語義の歴史的な経過を明らかにした。

Keywords : history book, Japanese dictionary of classical Chinese, book on ancient manners and customs, official goverment posts

\section{1. まえがき}

「土木」という言葉, つまり「土」と「木」の熟語で ある「土木」という言葉は古い言葉であると言われてい る.わが国では大化の改新あたりから使われ始めたとか, また「土木」という言葉は江戸時代には用いられず明治 時代になってから使われるようになったとか, さらに中 国では漢時代から使われてきたというように色々な説が あるが，しかし，この言葉の歴史的経過についてはこれ までに充分に明らかにされているとは言えないと考えら れる.

一般の人々の「土木」という言葉から受ける印象はあ まり良いものではないらしい.これは「どぼく」という 濁音が続く発音からくる感じと，「土」という文字から 連想する污い，暗い，感覚が強いからと思われるが，い ずれにしても，不当に悪い評価を受けている．このこと について，土木を専門とする人の中にも，これらの意見 に同調する者も多く，なお一層「土木」の印象を悪いも のにしている.このような傾向に対して, 土木学会では 昭和 62 年 9 月に「土木改名論を考える」という研究討 論会がもたれ，その反響も大きく，活発な討論がなされ たが「土木」に代わる他の言葉を見いだすような結論は 得られなかった.この改名論は,これまでにも数回起こっ ているが，その歴史は古く，土木学会が会誌を創刊した 大正四年四月，第一巻・第二号に早くも「土木」に代わ る言葉についての論評が出されて, 以後この事に対して 種々の意見が報告されている. しかし，この「土木」と いう言葉については礼賛論まではいかなくとも，あえて 改名する必要がないという意見もあり，今日まで他の言 葉に変わるまでに至っていない. また, 昭和 62 年 11 月 18 日を最初の「土木の日」と決め, 以後この日を「土木」

*正会員 工博 日本大学助教授 工学部土木工学科

( ₹963 福島県郡山市田村町徳定中河原 1)
に関する記念日にしたということもある.

そこで, 建築, 電気, 化学, 機械などという用語に比 ベ, 歴史的に古くから使われてきたこの「土木」と云う 言葉の語義の歴史的経過を詳細に調べた.

また，「土木」の同義語として, わが国では「普請」, 中国では「土功」という言葉があるが, その語源の中に は「土木の思想」ともいえるような意味合いを含んでい る.この二つの言葉が明治時代になって, 新しい「土木」 というべき言葉と変わっていったことを明らかにする.

\section{2.「土木」の語義に関する これまでの調査・報告}

ここで, これまで報告されている「土木」の語義につ いて，主なものを示すと次のようなものがある．これら の文献に関しては中国, 日本と分類して，それぞれにつ いての検討を次節でおこなう.

1）佐藤四郎; 『土木』是非 ${ }^{1)}$

土木ナル名稱八其意義二於テ……中略……

我邦文明ノ最初ノ輸出者夕ル支那二於テ如何二土木 ナル語フ使用セルヤ之き工事或八建築ノ意味二用工 ルヨリモ寧ロ之き醜悪又八污穢ナル形容詞トシテ使 用スルコト多キ二似タリ晋書・楼康傳, 嵇康字八叔 夜風度アリ形骸ヨ土木ニシ自藻飾セス人以爲ラク 龍章鳳姿天質自然ナリト爱二形骸き土木ニスト八其 ノ外貌キ修飾セス甚夕見苦シキギ形容セルナリ周書 二蘇綽門質アリテ才具ナキ人き嘲ツテ土牛木馬トイ フ之レ猶木土木二テ造リタル牛馬ノ形ノミ二似テ毫 モ其用き爲サ ノルキ罵シリシナリ或八土崩瓦解卜云 ヒ或ハ人木石二非ス卜謂ヒ何レモ劣悪ナル意味二用 ヒショ見ルベシ……以下省略.

2）石橋絢彦; 土木學ナル文字二詮議2)

支那ノ金石學卜日本ノ土木學八其文字卜内容二八甚 シキ違ヒアリ……中略……原来土木ナル熟字八後漢 
書殫ニ極 土木きョリ出テ、辭源二建築工程之キ土 木ト謂フトアリ又主作ノ二字ハ後漢書造二-起”九 廟空窮二極又土-作 謂フ也トアリ圭足ノ二字八禮記ノ註二瓦器き爲ル者 ヨ掌ル也トアリ锌源二殷ノ時ノ天子六工之一ニシテ 周二八司空二屬ストアリ土事ノ二字八禮記ノ土事 册レ作 二出テ、辭源二ハ興築之事ナリトアリサ レハ土木, 土作，土事八同意ノ字面ナルモ土工八異 ナリトイフヘキカ而シテ土木ノ二字ハ建築全體ノ廣 キ意味ヨリ出テ、今建築學會ナトノ建築ノ意卜異ナ ルナリ……以下省略

3）松尾春雄 ; 土木技術者の進べき道3)

大言海によると晋書, 稽康伝に「土木形骸, 不自藻 飾」とあって土木は身なりを飾らないこと, 粗野の 事であり, 日本でも近松作の會我扇八景に「内に土 木の気を養いて, 外, 青黄の色なく」とあり, 略々 同様の意味に用いられている. 工学に用いられた場 合にも土木が粗野な感じを与えるのは, その為もあ ると思う.

しかし近松が上記の文を書いた時, 土木を単なる抽 象的な意味に用いたものでなく, 土木を業とする者 の気質を連想していたように思える. 土木に從事す る者が, 単なる労役を提供する者であり, 教養のな い者の集まりであった事が，土木の意味を低下して いたには事実であろう。……略……序に土木が本 来の意味に用いられた例として大言海が挙げている のは次の二つである. 唐書, 百言志に,「工部郎中, 員外郎, 各一人; 掌城地土木之工役」とあり, 日本 では源平盛衰記; 24 , 南都合戦, 同焼失の事に「さ れば天平 17 年に, 土木の造縁を始められしに或は 力士, 変化の牛, 来つて材料を運び, 或は久米の仙 人，通力を起こして大木を飛ばし……」. とある.

4）真田秀吉; 土木と云う語4

字書によれば, 土木の字は晋時代 (300 年頃) に「抑 土木勝, 臣懼人心不安」の語あり, 此等土木の字は 建築も土木も総合的に使用した造営の意味の語で あって，専門語ではなかった。

明治以前の土木関係の著書には, 治水, 堤防, 橋梁 等の書に普請の字あるも土木の字なし. 明治四年発 行の地方汎例録には土普請の語あり.十三年内務省 土木局発行の土木工要録は, 主として治水工作物の 書であるが，初めて土木の字を用いた．前記の如く 土木の字を専門語となせるは, 明治以後のことであ る.

ここに示した報告以来「土木」の語義についての解釈 はしつくされたという事から, 曖昧さがありながら現在 に至っている.しかし, 中国文献, 日本文献とも「土木」 という言葉が使われている文献がまだ数多くあることか
らここれらも含めて「土木の語義」の歴史的変遷に関す る検討を試みた，さらに，明治以前は同義語の「普請」 あるいは「作事」という言葉が使われ「土木」は見あた らないと言われていることもあるので，この事について も調べた.

この「土木」という言葉が明治以前には使われていな かったと真田は前記のように報告している．しかし，内 務省史によると，「明治 2 年 4 月，太政官内に民部官を 設け，6月 4 日，「民部官職制」を制定し「土木司」な ど五司をおき,さらに，同 3 年 10 月工部省が新設され， 同 4 年 8 月に「土木寮」と改名されたとある.これらを 考察すると明治になってから「土木」という言葉を急遽 造ったようになってしまい, 不自然さは免れない. そこ で，このように，まだ充分に明らかにされたとはいえな い「土木」という言葉の「アイデンティティー」を確立 したいと考えている.

\section{3. 中国の文献に現れる「土木」の語義}

わが国に漢字をもたらした中国における「土木」とい う言葉について，その語義とそれの歴史的経過について 考察する. 中国文献に現れる「土木」という言葉の語義 について, 漢和辞典としては最も著名な諸橋轍次著『大 漢和辞典』（大修館書店）を始め, 史記, 漢書, 後漢書 などの「中国二十四正史」(中華書局出版), 周礼, 尚書, 列子なよ゙からの出典により，「土木」という言葉の変遷 について調べ，それが現在と同じ意味に使われるように なった時代を明らかにしたい.

現在のわが国の「建設省」に相当する中国の歴史的官 職には司空, 共工, 冬官, 将作, 工部などがあり, また 特に河川, 運河, 治水, 灌溉など「水」に関することを 司ビるものに都水あるいは都水監などがある．「土木」 に関する用語は，これらの官名について記せられたもの に出てくることが多い. そこで, 官職からも「土木」の 語義を調べてみた。

\section{3. ( 1 ) 『大漢和辞典』にある「土木」の語義について の検討}

この辞書はわが国で発行されている漢和辞典では最も 収録漢字数が多く, また, 詳細なものであり, 参考文献 の引用も多い.そこでこの辞書にある「土木」という項 目およびそれに関連する用語についての記述内容を検討 する．多少引用が長くなるが正確さを記すため項目の全 てを載せる。

【土木】、゙ボク ( 1 ）家づくり.ふしん. 又, 建築・ 築堤・道路開籢等の工事.

〔國語, 互語九〕今土木勝, 臣懼其不安人也. 〔列子, 天瑞〕禾稼土木. 〔後漢書, 郎顗傳〕土木營建. [北史, 齊後主紀]詔, 土木營造, 金銅鐡諸雜作, 
一切停罷.（2）飾らないこと.ぶこつ. 粗野.〔晉 書, 秋康傳了秋康字叔夜, 有風土, 而土木形骸, 不 自藻飾.（3 ）堡の名．唐，置く．察哈爾省懷來縣 の西．もと統漠鎭といふ．土木はその訛．〔讀史方 興紀要, 直隷, 萬全都指揮使司, 延慶右衛了西南二 十五里，地界相錯爲往來之孔道，本名統漠鎭，唐末 高開道據懷戎時所置, 後叱爲土木永樂初, 置堡此.

上記の中で最初の $(1)$ )の家づくり，ふしん，築堤等の 土木建設工事を意味する「土木」の出典として，『國語』， 『列子』，『後漢書』，『北史』をあげているので，これら について考察する。なお，それ以外の語義としてあげら れている「粗野」などについては，6 章で検討する.

〔國語，晉語九〕今土木勝，臣懼其不安人也.

いま, 大野峻著『國語』(明治書院・新釈漢文大系 67) によって，その出典之読み下し文をあげれば，次のとお りである。

[出典］智襄子爲室美，士茁夕焉. 智伯曰室美夫.

對曰，美則美矣，抑臣亦有懼也．智伯曰，何懼. 對 曰，臣以秉筆事君，志有之曰，高山峻原不生草木， 松柏之地, 其土不肥, 今土木勝, 臣懼其不安人也. 室成三年而智氏亡.

[読下文］智襄子室を爲りて美し，士茁夕す．智伯 日く室は美しきかな，と．對へて曰く，美しきこと は則ち美し，抑々臣も亦懼るる有り，と．智伯曰く， 何を加懼るる，亡．對へて曰く，臣筆を康ることを 以て君に事了，志に之れ有り曰く，高山峻原は草木 を生ぜず，松柏の地は，其の土肥えずと. 今土木勝 てり，臣懼らくは其の人を安んぜざることを，と。 室成りて三年にして智氏亡ぶ.

『國語』は，周の左丘明の作といわれ，春秋時代の歴 史を各国別に記したもので，その中にある「知伯家を美 しく建てて滅亡する」の一節である。これはしたがって， 「土木」の最も古い出典の一つと考えられる.これにつ いて，大野氏は，

茁「わたくしは筆をとって君に事えておりますが, 記録にこう書いてあります。『高山や高原に草木が 生えず，松やひのきの生えている地は，その土は肥 沃ではない』と．今土木が勝っていますので，わた くしは，そこに住む人を安泰にさせまいことが心配 なのです」．家ができ上がって三年で智氏は滅んだ. 亡解釈されている．ここでは「土木」が何を意味するか については，具体的に示されていない．しかし，前後の 文章から判断すると，ここにある「土木」は前後の関係 から，「家づくり」，つまり「建築」を意味していると考 えられる．すなわち智氏は家（支配者としての豪華な宮 室）を造ることばかりに力を入れすぎて市民の生活を顧 みなかったので新しい家ができて後，わずか三年で滅ん だと解釈される。したがって現在の「土木」と同義語と
は考えにくい.

[列子, 天瑞第一, 第十六章 $]$ 禾稼土木

小林信明著『列子』(明治書院 - 新釈漢文大系 22) に よって，その出典之読み下し文をあげれば，次のとおり である.

[出典］國氏日，……生吾禾殖吾稼, 築吾垣建吾 舎. 陸盗离獸, 水盗魚鿀亡非盗也. 夫禾稼土木, 离 獸魚敬，皆天之所生，豈吾之所有. ……

[読下文］ 國氏日く，……以て吾が禾を生じ吾が稼 を殖し，吾が垣を築き吾が舎を建つ．陸に禽獸を盗 み, 水には魚檠を盗む. 盗に非ざるは亡し. 夫れ禾 稼土木, 禽獸魚整は, 皆天の生ずる所, 豈吾の有す る所ならんや. .......

『列子』は戦国時代の道家, 列禦寇の著作といわれて いるが，魏・晉時代の偽作という説もあり多くの疑問も 含まれている書といわれている。ここにある「禾稼土木」 は以生吾禾殖吾稼, 筑吾垣建吾舎に対する禾稼土木で, 小林信明著『列子』（明治書院・新釈漢文大系 22）は, 「稲をそだて穀物をしげらせ，垣根を築き家を建てる。 ……思うに, 作物を始湕築材料, さては鳥獣から魚類 まで……」解釈している. ここの「土木」は, 垣や家 を建てるための建築資材を意味する言葉とするのが妥当 であろう。

[後漢書, 郎顗傳 $]$ 土木營建

この文献は日本語に解釈されたものがない，筆者が范 嘩編『後漢書』(中華書局・北京) を読み下した.

[出典］一事. . 陵園至重，……西苑之設 禽畜是 處，離房別觀，本不常居，而皆務精土木，營建無己， 消功單賄, 巨億爲計.

[読下文］ 略……西苑を設け，禽畜を是に處，房 を離して別觀とし，本は常居せざるなり．而して皆 土木に精出し，營建すること止むことなし，功を消 し單に賄うに，巨億の計を爲す。

『大漢和辞典』の $(1)$ の三番目にある「土木營建」は『後 漢書』にでてくる．この書は後漢の正史であり，南北朝 時代の宋の范嘩が編纂したものである. 出典の内容は郎 顗が後漢の順帝に陳じた「便宜七事」の中の一つで，ここ の「土木」は宮殿を建てたり庭園を造ったりすることと 解釈される.これより土木, 建築の両義と考えられるが， 現在の感覚からは建築的な意味あいか強く感じられる.

[北史，齊後主紀］土木營造

この「土木營造」は前述の「土木營建」と同義と考えら れる.

これらのことから『大漢和辞典』にある出典は,「土木」

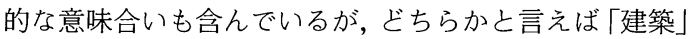
的な事を意味する言葉として解釈され，現在我々が用い ている「土木」，つまり架橋，築堤，道路建設などを意 味している言葉と同義とは考えにくい. 


\section{3. (2 2 )『大漢和辞典』に見える「司空」「共工」「冬官」} 「将作」「工部」に於ける土木の語義

土木関係の役名は中国においては非常に古い文献から 出ている．このこととは中国文明が「黄河を治める」こ とから始まったといわれることからも理解できる。ここ で，取り上げた土木に関する職官名は二十四正史（中華 書局出版・北京）にある「職官」，「百官」および『歴代 職官表』（上海古籍出版社）から選んだ。『大漢和辞典』 の諸橋は工部の説明として「その起源は堯, 舜の時代に 發し, 即ち, 唐盧の時, 禹を司空として水土を掌らしめ, 垂を共工として百工の事を掌らしめたことより始まる.」 と言っている。このことから中国における土木職名とし ては, 司空, 共工が古い職名で, 冬官となり, 次に将作, 工部というように変化していると考えられる.ここで, 最初に司空，共工を前述の文献および二十四正史により 示すとつぎのようになる.

【司空】官名. 少吴の時, 置く. 唐盧以後, 之に因る. 周代には六卿の一つとなり，冬官，大司空といひ， 水土の事を掌る. 漢は御史大夫を改めて司空とし, 大司馬・大司徒と共に三公に列す.後, 大の字を去っ て司空亡いひ，歴代，之に因る．明，廢す．後人， 工部尚書を通稱して大司空といふ.

[書, 舜典] 僉曰, 伯禹作司空.

[蔡傅］平水土者司空之職.

[書, 周官］司空掌邦土居四民時地利.

【共工】堯の時，水を治めた官.

[書, 堯典] 都共工, 方鳩叞功. 「鄭注」共工, 水 官名，其氏名未聞.

[書, 舜典] 流共工干幽洲.「釋文」少氏有不才子, 毀信廢忠, 云云, 天下之民謂之窮奇杜預云, 即共工. 舜の時, 百工の事を掌った官.

[書, 舜典] 垂汝共工.「鄭注」初堯冬官為共工. [史記，五帝紀］以垂為共工.

このうち「司空」の蔡傳にある「平水土」は，水や土 地のことを平らかにし，治める意味で，土木行政に関す る官名と解釈できる．同じく「書，周官」の「掌邦土」 は国土のことを司どる，という意味でやはり土木に関係 している事が分かる.

また， [共工] の出典の「書, 堯舜典」の解釈につい ては，これを人名にするものと官名にするもの之二通り あるが, 前後の関係からは人名とする説が多い.さらに, 「書，舜典」および「史記，五帝紀」の「共工」につい ても二通りの解釈があり明らかでない。他に吉川幸次郎 の『尚書正義』の中にある堯典の孔伝に，「共工は官称」 とあるが，これらの出典では土木に関係する官名かどう かははっきりしない.

続いて冬官, 將作, 工部についてのべる. 出典は『大 漢和』および二十四正史による.
【冬官】周代，六官の一. 土木工作の事を掌る.

[周禮，天官，少宰］六曰，冬官，其屬六十，掌邦 事.

[周禮，冬官，考工記第六，疏］鄭目録云，象冬所 立官也，是官名司空者，冬閉蔵萬物，天子立司空， 掌邦事，云云.

これは周代に使われた官名で司空と同じものである. しかし，これまでの出典には土木という言葉は出て来な い.

【將作】官名. 將作少府という. 秦, 置く. 宮室の造 営を掌る. 周の考工の職. 漢の景帝の中元六年, 將 作大匠之改め, 後漢, 之に因り, 宗廟・路寝・宮室・ 陵園の土木の工を掌る.魏・晉も亦之に因り,東晉・ 宋・齊には事ある毎に置く。梁・陳には大匠卿之稱 し北齊には其の官を將作大匠,官署を將作寺と稱す。 後周には匠師中大夫があり，城郭宮室の制を掌り， 別に司木大夫を置いて土木に政を掌る. 随には将作 監と稱し，官を將作大監・少監，或は將作大匠・少 匠と號す．唐は大體，將作監・営繕監と稱したこと もあり,土木工匠の政令を掌り,左校・右校・甄官・ 中校の四署を領す．宋・遼を經て，金には省く，元 には將作院があるが，其の掌る所は金・玉・犀・象 等の服飾，刺繝の製造で，土木等のことは繥工司・ 修内司・祇應司等が掌る.明・清には営繕司を置く. [漢書, 百官公卿表] 將作少府, 秦官, 掌治宮室有 両丞-左右中候, 景帝中六年, 更名將作大匠, 属官 有石庫・東園・主章・左右前後中校・七令丞.

ここからの出典,つまり『後漢書』から『宋史』まで は二十四正史によった.

[後漢書，志，第二十七，百官四］將作大匠一人， 二千石. 本注曰; 承秦, 日將作少府, 景帝改為將作 大匠. 掌修作宗廟, 路寝, 宮室, 陵園木土之功, 开 樹桐梓之類列于道側. 丞一人, 六百石.

ここに示した漢書, 後漢書の文献には土木という言葉 はでてこないが，後漢書にある「木土之功」は「土木之 功」と同じであり, 建築的な性格が強いが, 多少土木工 事も意味する言葉である。ここで，「土木」が現在の建 築的な意味を現していたのに対し，「土功」という語句 が現在の土木建設を意味する言葉として，この頃の文献 に多く使われている.

[晉書, 職官] 將作大匠, 有事則置, 無事則罷. [宋書, 百官上] 將作大匠, 一人. 丞一人. 掌土木之役. 秦世置將作少府, 漢因之. 景帝中六年, 更名將作大匠. 光武建武中元二年省, 以謁者領之. 章帝建初元年復置. 晉氏以来，有事則置，無則省. [南齊書, 百官] 將作大匠. 太僕. 大鴻. 三卿不常 置. 奬作掌宮廟土木.

[随書, 百官上] 天監七年……將作大匠爲大匠卿, 
……匠卿, 位視太僕, 掌土木之工. 統左, 右校諸

署.

[随書, 百官中] 將作寺, 掌諸営建. 大匠一人, 丞 四人.

宋書には「掌土木之役」, 南齊書には「掌朝廟土木」, 随書には「掌土木之工」というように「將作」の説明に 「土木」という語句がでてきて，その仕事あるいは工事 を司どるとある.しかし，「土木」の具体的な内容を示 した言葉はでてこない。 おそらく, 現在の土木, 建築の 両方の意味を含んでいる言葉として用いられていたもの と考えられる．このことは唐書あるいは宋史になると一 層明からかになってくる。

[唐書, 百官三, 將作官] 監一人, 從三品; 少監二 人, 從四品下. 掌土木工匠之政, 總左校, 右校, 中 校, 甄官等署, 百工等署. 大明, 興慶, 上陽宮, 中 書, 門下, 六軍仗舎, 閑廐, 謂之内作; 郊廟, 城門, 省, 寺, 臺, 監, 十六衞, 東宮, 王府諸廨, 謂之外 策. 自十月距二月, 休冶功; 自冬至距九月, 休土功. 凡治宮廟，太常擇日以聞.

[宋史, 職官五, 將作] 旧制, 判監事一人, 以朝官 以上充. 凡土木工之制，京都繥修隷三司修造，本監 但掌祠祀，供省牲牌，鎭石，量香，榓手，焚版弊之 事. 元豐官制行, 始正職掌. 置監, 少監各一人, 丞, 主簿各二人. 監掌宮室, 城郭, 橋梁, 舟車営繥之事, 少監為之武, 丞参領之. 凡土木工匠板築造作之政令 總焉.

ここに示された唐書，宋史にある「掌土木工匠之政」 は土木および工匠の二つ役割を持っているため，いまの 土木の仕事内容と異なるものも含んでいるが，唐書にあ る「休土功」あるいは宋史にある都の修造, 城郭, 橋梁, 板築などは土木あるいは建築に関係することがらであ り，ほぼ現在の建設と同義に使われている．元には將作 院という官名があったが，土木には関係なく，これとは 別に「工部」が治水を除く土木の仕事を司に゙っていた。 諸橋はこのほかに繕工司, 修内司等を土木関係のことを 掌る官署と記しているが，これらは宮殿の建設，修理や 大都の造作, また, 府内の諸王邸の建築など, 土木とい うよりは建築的な事にあたっていたものである.

つづて「工部」について『大漢和』より一部を引用 すると,

【工部】官署の名. 六部の一. 営造工作の事を掌る. この名稱は六部の制度の完備した随唐の時に起こっ た.工部の名は後周为，冬官大司空を置き，其の下 に工部中大夫を置くに始まるが，其の職制は随代六 部の制を設けたのに因って備はる．唐は之に因り， 工部尚書一人を長とし，侍郎一人を副とし，工部・ 屯田・虞部. 水部の四曹各郎中一人を置き, 城池土 木の程式, 天下の屯田, 在京官の職田, 公綮, 京師

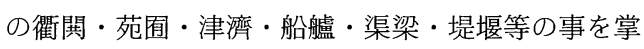
る. 宋の元豐の官制には天下の城池・宮室・舟車 · 器械符印・錢寶の事及び百工・山澤 · 溝洫 · 屯田の 政令を掌る. 紹興三年, 少府監を併せて工部に歸し, 文思院を以て属す。元には修造・営建法式・諸作工 匠 ·屯田 ·山林 · 川澤の禁並に江河 · 堤岸 · 道路 · 橋梁の事を掌る. 以後, 大體に於て大なる変化はな く, 清代は尚書滿漢各一人, 左右侍郎各一人を置き, 其の下に営繕 - 䖒衡 - 都水 • 屯田の四清吏司が付属 し, 主として土木工事の監督, 軍需品・弾薬の製造, 宮廷及び官用の器物・船舶・製作等を掌つたが, 光 緒三十二年の官制改革によって，農工商部に併合せ らる. 別に将作・都水の官は秦漢以来独立していた が，明代に至り全く工部に併合せられた。

[事物紀原, 三省綱轄部, 工部] 工部, 唐䖒共工, 在周禮爲冬官之職, 漢置民曹, 光武改主繕修工作池 苑, 魏爲左民, 晉尚書爲起部郎, 後周始曰工部也.

ここで，『随書』から『明史』までは二十四正史で，『清 曾典』は『大漢和』の出典である.

[随書, 百官下] 高祖既受命, 改周之六官其所制名, 多依前代之法. ……公及尚書……将作寺等, 云云, 工部尚書統工部, 屯田侍郎各二人, 盧部, 水部侍郎 各一人.

[唐書, 百官一］尚書一人, 正三品; 侍郎一人, 正 四品下. 掌山澤, 屯田, 工匠, 諸司公廨紙筆墨之事. 其屬有四：一曰工部，二曰屯田，三曰㲊部，四曰水 部. 工部郎中, 員外郎, 各一人, 掌城池土木之工役 程式, 爲尚書, 侍郎之負. 凡京都営繕, 皆下少府, 将作共其用, 役千功者先奏. 凡工匠, 以州縣爲團, 五人爲火, 五火置長一人. 四月至七月爲長功, 二月, 三月, 八月, 九月爲中功, 十月至正月爲短功. 雇者, 日爲絹三尺, 内中尚巧匠, 無作納資. 凡津梁道路, 治以九月.

[宋史, 職官三] 工部掌天下城郭, 宮室, 舟車, 器 械, 符印, 錢幣, 山澤, 苑直, 河渠之政. ……道 路, 津梁, 以時修治. 尚書掌百工水土之政令, 稽其 功緒以詔賞罰.

[元史, 百官一] 工部, 尚書三員, 正三品, 侍郎二 員, ……掌天下営造百工之政令. 凡城池之修漟, 土 木之繥亘, 材物之給受, 工匠之程式, 銓注局院司之 官, 悉以任之. 云云.

[明史, 職官] 工部尚書一人, 左右侍郎各一人, 其 屬司務廳司務二人，営繥 - 盧衡 - 都水 · 屯田四清吏 司各郎中一人, 員外郎一人, 主事二人, 云云, 尚書, 掌天下百工山澤之政令侍郎佐之.

[清曾典, 工部] 工部尚書, 滿洲一人, 漢一人, 云 云，掌天下造作之政令，與其經費以贊上奠萬民，凡 土木興建之制, 器物利用之式, 渠堰疏障之法, 陵寝 
供億之典，云云.

以上, 随書から清曾典に至るまで示したように「工部」 は「將作」と同様に土木建築等を掌っていた官名であり， ここで用いられている「土木」の語義は現在の「建設」 と云う言葉とほぼ同義であると考えられる.

\section{3.（3）種々の中国文献に現れる「土木」}

これまでに，『大漢和辞典』を中心に官職の歴史的経 過などから「土木」という言葉について，その語義を述 べてきた.ここでは，その他の文献に現れる「土木」と いう言葉を年代順に列記し検討する.

[列子, 周穆王第三] 穆王乃爲之改築, 土木之功, 赫惡之色, 無遣功焉.

[列子，仲尼第四]伯㘒子不應，伯豐子之從者，越次 而進曰, 大夫不聞齊 - 魯之多機乎, 有善治土木者. 有善治金革者.

[後漢書, 梁統列傳 $]$ 冀乃大起第舍, 而壽亦對街爲 宅, 殫極土木, 互相誇競.

[後漢書, 宦者列傳] 狗馬飾雕文, 土木被綺紼.

[至書, 志第十七, 五行] 桓玄始纂, 龍旂竿折. 時 玄田獵無度, 飲食奢恣, 土木妨農, 又多姦謀, 故木 失其性.

[宋書，第二十九，百官］材官將軍，一人．司馬一 人. 主工匠土木之事. 漢左右校令, 其任也. 魏右校 又置材官校尉, 主天下材木事.

[陳書, 列傳第四, 程靈洗] 文季臨事謹急, 御下嚴 整, 前後所城壘, 率皆乍水爲, 土木之功, 動踰數萬. [宋史, 食貨下, 會計] 自是道家之奉有節，土木之 費省矣.

[宋史, 食貨下, 會計] 是歳, 詔内外勿給土木工作, 非兩宮, 倉虞.

[資治通鑑，巻四十四，漢紀三十六年］秦曰將作少 府, 景帝改為將作大匠. 掌修作宗廟, 路寝, 宮室, 陵園土木之工, 开樹桐之類, 列於道側.

[資治通鑑，巻五十三，漢紀四十五］冀與壽對街爲 宅，殫極土木，互相誇競

[續資治通鑑長編, 巻二, 太祖 建龍二年 $]$ 九月甲 子, 以荆南行軍司馬……中略……又好營造臺榭, 極 土木之功, 軍民咸怨.

[清史稿，志八十九・職官一］ 民政部，民政大臣， 副大臣……光緒三十二年, 更名農工商部, 省節慎庫, 併土木工程入民政部……

ここに示した「土木」という言葉は現在の感覚からい うと，「土木」よりはどちらかというと「建築」的な意 味合いのほうが強いが，両方を含んでいる「建設」とい う意味に解釈するのが妥当であると考えられる.このう ち［列子，仲尼第四］にある ‘有善治土木者'は「よく 土木を治める者あり」と解釈され, 大漢和にある [列子,
天瑞］の“禾稼土木’の出典よりもより良い例と考えら れる.

\section{3. (4) 築土構木について}

土木という言葉の語源として「築土構木」を上げ, そ の出典として『淮南子』としている報告5)があるので, これについて考察する.「築土構木」は『淮南子』の中 の巻十三氾論訓に現れるが，その部分を楠山春樹『淮南 子』（明治書院・新釈漢文大系 55）によって, その出典 と読み下し文をあげれば，次のとおりである.

[出典] 古者民澤處復穴, 冬日則不勝霜雪霧露, 夏 日則勝暑熱虫䖟, 聖人乃作, 爲之築土構木, 以爲室 屋, 上棟下宇, 以蔽風雨, 以避寒暑, 而百姓安之.

[読下文］古者は民, 澤處し復穴し, 冬日は則ち霜 雪霧露に勝へず，夏日は則ち暑熱蝁䖟に勝へず，聖 人乃ち作り, 之が爲に土を築き木を構へて, 以て室 屋と爲し, 棟を上にし宇を下にして, 以て風雨を蔽

ひ，以て寒暑を避けしめ，而して百姓之に安んず.

『淮南子』は, 前漢の武帝のころ, 淮南国の王であっ た劉安 (高祖の孫) が, 食客として抱えていた大勢の学 者に命じて編纂させた書であって, 表向きは彼自らの撰 著として今日に伝えられているものである. 楠山は次の ように通釈している.

[通釈文］むかし民は，湿地に住み，穴ぐらに暮ら していたから, 冬は霜雪・霧露に堪えられず, 夏は 暑さや蚊・虬に堪えらなかった. そこで, 聖人が出 て，民にために土を盛り材木を組んで室屋を造り，

棟木を高くし軒を低くして，風雨をしもぎ，寒暑を 避けるようにさせた。

これより,「築土構木」とは単に盛り土して家屋を造 るという意味で, 『国語』や『列子』で示した「土木」 と同じであり，無理に「築土構木」を「土木」の語源と することはないと考えられる.

\section{4. わが国の文献に現れた「土木」}

「土木」という言葉についていつ頃から使われたかに ついて, 椎貝は「大化の改新」あたりから始まると考え てよいと述べている6). しかし，このころの文献として は古事記，日本書紀があるが，これらの中には「土木」 という言葉はまったく見あたらない. さらに下って，そ の後の歴史書である続日本紀, 日本後紀あるいは延喜式, 交替式などにも出てこない.「土木」という言葉が使わ れだしたのは平安時代末期であるらしい. また，平安末 期, 橘忠兼が編纂した古代国語辞書である『色葉字類抄』 には, 「土木, 伎芸, トボク, 工匠又造作名也」とある. ここで, 種々の文献に現れた「土木」について, 出典, 時代, 解釈について検討する.

[權記] 長保四年三月十九日, 乙卯, 召使有忠来告, 
……中略……諸道勘申火災由縁，事旨廣多，是以儉 約可消其災火之趣也，仍營造之間，重制過差，不費 土木之功力，可柱梁之高大，然吏民經營自省其煩， $\ldots .$.

権大納言藤原行成の日記. 長保四年は西暦で 1002 年 となり平安中期である.

これは, 火災により宮殿が焼失し, 再建することになっ たが，この際倹約を第一に考え，柱を高くしたり，梁を 大きくするのは止めるべきだ, という意味に解釈できる. それでここの「土木」は造宮のための工事を指してい るので, 建築的な意味あいが強く感じられ，現在使われ ている意味での「土木」とは考えにくい.

[兵範記］久安五年十月廿五日癸酉 天晴，成樂院 中御堂供養也, 是非御自願，奉爲故北政所，去夏企 土木, 其功速終, 今日被遂供養也, 三間四面檜皮莫 御洞一宇, …....

西洞院兵部卿平信範の日記. 西暦 1149 年で平安末期, ここにある「土木」は「成樂院中御堂が完成したので今 日供養した」とあることにより, 寺院など宗教関係の建 物を造ったと解釈され，『權記』の「土木」と同じ意味 亡考えられる．さらに，これらと同義と考えられる文献 を次に上げる。

[吾妻鏡］ 建久六年三月十二日丁酉，朝雨䨍， 中略…… 今日東大寺供養也, $\cdots \cdots \cdot$ 文治元年 $\cdots \cdots \cdot$ 同二 年丙午四月十日, 始入周防国, 抽採料材, 致柱礎構, 企土木功載柱一本之車, ……

[擬香山模草堂記] 賀草堂新成詩 白氏鑪峯伝昔様 斯栖元白属幽閑 池模蓮府古時水 月似虎谿秋夜山 翠萾掩空松百丈 草堂模跡竹三間 爱營土木日々攀

［空華日用工夫集］永和二年八月五日邀請圓造營奉 行官人上杉刑部等……中略……限三年以十州管内關 税棟別及鎌倉中諸課役等充之暫停他寺社土木事 [山門堂舎記] 常行三昧院. ……中略……此堂四種 三昧之其一也. 伝教大師弘仁九年七月廿七日, 分諸 弟子配四種三昧, 令慈覚大師経始常坐三昧堂. 同九 年土木功畢，自入三昧，六年修行．……以下略

[神皇正統記 $]$ 第七十二代. 第三十九世. 白河院 ……中略……城南の鳥羽と云所に離宮を立. 土木 の大いなるいとなみ有き。むかしはおりるの君は朱 雀院にまします.

さらに,「土木」という言葉が使われている同時代の 文献には方丈記, 源平盛衰記があり, これまでの報告に も引用されているが，この二つについて若干の検討を加 える.

[方丈記］その時，おのづからことの便りありて， ……中略……もとよりこの所にをるものは，地を失 ひて愁ふ，今移れる人は，土木のわづらいあること
をなげく．道のほとりを見れば車に乗るべきは馬に 乗り衣冠，布衣なるべきは多く直垂を着たり．…… 鴨長明作，鎌倉時代の随筆. 治承四年の福原遷都の之 ころである.ここの「土木のわづらい」については，前 後の関係加, 現在使われている「土木」と同義と解釈 している報告もあるが，江戸時代の注釈書『誢説』，『謗 解』, 『流水抄』, 『宜春抄」などはじめ, その後の注釈書 により種々の解釈がなされているが，それらは建築材料 説と家屋敷を建てるという説に集約され，土木的な意味 として解釈しているものは一つもない.

[源平盛衰記・廿四] (国民文庫刊) されば，天平十 七年に，土木の造縁を始られしに，或は力士變化の 牛來て料材を運び, 或は久米の仙人通力を起て大木 を飛し，或は雷神磐石を碎て船筏を下き。……

作者不詳. 天平十七年に「土木の造縁」を始めたとあ るが，造縁という言葉は辞書にはなく，これはおうらく

「造営」か「造宮」の誤写かと思われる．この「土木の 造縁」(原文のまま) とは, 東大寺の建立を開始したと いう意味であるから，現在の感覚からすると，土台など の基礎工事等一部土木的な仕事が含まれてはいるもの の, 多分に建築的要素が強く, いま使われている「土木」 とマッチしたものとは考えづらい.

これまでに示した文献は，すべて平安末期から室町時 代のもので，それ以降の文献には「土木」の語は見あた らず，同義の言葉としては「普請」あるいは「作事」が 用いられている. 中世の種々の文献に出てくる「土木」 は，すべて寺院を建てるなどの現在の「建築」と同義に 解䣋され，これは，古い中国文献の「土木」と同じであ ると考えられる.ささらに，土木という言葉が出てくるの は江戸時代末であるが，やはり主流は「普請」，「作事」 であり「土木」という言葉が使われている例はほとんよ゙ なかったと思われる.

\section{5.「土木」という言葉の成立}

中国の場合と同様にわが国の土木建設に関する職制か ら「土木」の語義を調べる.『古事類苑』官位部にある 修理職, 造宮職, 土工司, 木工寮, 作事奉行, 普請奉行 にでてくる土木という言葉は, 明治期の編集時に書かれ た解説文をに除いて, 種々の引用文献の中では木工寮の

[唐六典二十三將作監］將作監大匠一人從三品……

中略……將作大匠之職掌供邦國修建土木工匠之政令 總四署三監百工之屬……以下略

之普請奉行, 諸奉行の数多くの引用文献のうち『武家名 目抄』に現れるだけである.このうち唐六典は中国の明 代の文献であるので, わが国の文献としては『武家名目 抄』が唯一となる.

ここで, 『武家名目抄』とは江戸幕府の命により, 塙 保己一, 山中信名, 松岡辰方, 和学講談所員等によって 
編纂された江戸時代後期（万延元年 1860 年）の武家故 実書で全 381 冊からなっている.これは, 武家に関する 名称・品目を掲げ，それに関する古書や旧記を引証して 解説した書物. 鎌倉時代以後の武家諸般の名称, 品名を 職名・呼称・居拠・衣服など十六部門の分類し，それぞ れに，その典拠を示して説明したものである．武家政治 の体制を知るための重要な文献である. そこで, これに ついて詳しく文献を引用して考察する.

【武家名目抄】

[作事奉行]

按作事奉行は殿舎の修造より始めて土木のことは何 事に限らすすへてふさぬるつかさなれは其方にては むねとの所職なり……中略……それより後には土木 のことあることに大かた奉行人の内にうけ給はり沙 汰することとはなりぬ……中略……足利殿の世とな りては五カ番衆の内より作事奉行普請奉行の兩職を さためて共に土木のことに従はしめ又奉行人の内よ り其事に勾當すへきものを定めて兩奉行と同しく土 木を掌らしむ……中略……普請奉行は作事奉行と 共に事を沙汰するなかにやや職掌の差別あり作事に 方は屋舎の修造をむねとし普請の方は土地につきた ることを専務とせしなり……

[普請奉行]

按普請奉行は作事奉行と共に土木のことをふさぬる つかさなれと各職掌に差別あり作事といへる方は營 作屋宇の修造をむねとし普請といへる方は築き地を ならす等の事を専務とせり凡普請といへるはもと僧 家の語にして普く天下に請て堂塔を営建する意より 出たる辭なれは俗家に作事といふに異なることなき いはれなるを中頃よりのならひにて殿舎堂塔等造作 の事を作事といひ城壁堤防墻垣なと修築するを普請 といひしより作事普請と兩職には分れしなりされと もと一致の司なれは土木の役ある時は兩職ともにあ つかりきく事常の事なり……

\section{[普請衆]}

按普請衆といへるは幕府にもあれ大名にもあれすへ て土木のことある時幕府にては大名後家人に仰せ大 名にては被管家子なとに令して人夫を出さしめ土を ならし砂石を運ひなたすることを役せしむ……略

上述のように，この文献には「土木」という言葉がし ばしば現れ, 普請奉行, 作事奉行なよ゙について解説して ある部分に使われている.これによると, 作事, 普請の 二つを一緒にしたのが「土木」という言葉になって用い られている. また，このうち「普請」という言葉が現在 の「土木」であり「作事」が「建築」を現す言葉である ことがわかる.このような事から, 江戸時代から既に, 現在の土木と建築の両方の意味を含んでいる「建設」と いう言葉と同義語と考えられる「土木」という言葉が成
立しており，明治政府の成立と共に制定された職制の中 に「土木」という言葉が使われたのは，ごく自然なこと であるといって良い，さらに，「土木司」あるいは「土 木寮」など「‥司」,「‥寮」という名称を用いたのは王 政復古により, 武家時代の職制である老中, 目付, 奉行 などに代えて平安時代の職制である「大宝令」を参考に したためであり，「土木司」，「土木寮」という明治の職 名は「土工司」あるいは「木工寮」という律令制度にあ る職名と『武家妙目抄』にある「土木」との組合せによ り出来た職制と考えられる.

\section{6. 従来の「土木」の語議に関する諸説の検討}

はじめに『國語・丝語』の「今土木勝」の解釈につい て, 小泉純一著『しびるえんじにありんぐえっせい』(山 海堂出版）に次のようにある.

最初の晋語の文の解釈について, 近くの高校の先生 にお聞きしたところ，「今，土木まさに臣らその人 を安んぜざるを，おそれるなり」と読み下し，「土 木がしっかりしておればビクビクおそれる必要はな い」と解釈するそうである. 紀元前の極めて昔の時 代から中国では土木という成語があり，現在とほぼ 同様の意味で使われていたようである．ただその時 代にも建築との区別があったのか, 大漢和辞典に(マ マ）土木の引例だけではわからない. .......

この解釈は 3. (1) で記した大野峻の解釈と比較する と全く逆の解釈になってる. しかし，「土木がしっかり しておればビクビクおそれる必要はない」と解釈すると, その後に続く「室成三年而智氏亡」とはつながらない. また，『國語・周語』の中には「土功」という言葉があり， さらに左丘明作といわれている『春秋左伝』にはこの「土 功」という言葉がしばしば用いられ，その語義は現在使 われている「土木」とほとんど同じ意味であり，その後 の種々の中国文献にも土木工事を意味する言葉として 「土功」が多く用いられていることからも，ここでの「土 木」は建築と解釈するのが妥当であると考えられる.こ れについては次章で考察する.

つぎに，直接の土木の意味とは関係しないが 2 章の ‘『木』是非’のなかで佐藤四郎が「土木」という言葉 の意味として醜悪または污穢の形容詞としての仕様例に 上げた「土木形骸」について考察する.

[晉書・嵇康傳 $]$ 嵇康字叔夜, 譙國銍人也. 其先姓奚, 會稽上㲊人, 以避怨, 徙焉. 家于其側. 因而命氏. 兄喜, 有當世才, 歴太僕, 宗正. 康早孤, 有奇才, 遠邁不营. 身長七尺八寸, 美詞氣, 有風儀, 而土木 形骸, 不自藻飾, 人以爲龍章鳳姿, 天質自然. 恬靜 寡欲，含坧匿珢，寛簡有大量.

(中華書局出版・北京)

この「土木形骸」について, 佐藤は「污らしく見苦し 
い身なり」という意味に解釈している.しかし，これを 正確に解釈すると，「土木形骸」とは「単に身なりを飾 らない」というだけで, 前後の文章からみてもとても「污 らしく見苦しい」という意味とは考えられない．つまり 秠康は身なりを飾らなくても生まれつき風采の立派な人 であると解釈するのが自然で, 生まれつき風采があり, 言葉, 気持ちが美しく作法にも優れた人がいくら身なり にかまわないからといっても，污らしく見苦しいとはい いがたい，佐藤の解釈は無理に「土木」という言葉を卑 下していると考えざるをえない.

また，2 章で松尾が示した『曾我扇八景』にある土木 について考察する.「土木の気をやしない」という文章 がでてくるのは，その冒頭の部分であり，以下に示す.

[曾我扇八景］相鶴経に曰鶴は. 一百六十年にして 雌雄相見てはらみ.一千六百年に胎化してうむとい へり. 又曰. 内に土木の気をやしなひて外青黄の色 なく. 天寿をのづからはかりなく聖人位にあるとき んば.鳳凰にともなつて砌にあそぶ池水や。いはほ の松に千代ふべき所見たてて鶴が岡.

（解説注釈大近松全集 10）

近松門左衛門作の浄瑠璃の一節であり, この浄瑠璃に でてくる「土木」の解釈について松尾は次のように述べ ている.

しかし近松が上記の文を書いた時，土木を単なる抽 象的な意味に用いたのではなく，土木を業とする者 の気質を連想していたようにも思える. 土木に従事 する者が, 単なる労役を提供する者であり, 教養の ない者の集まりであった事が，土木の意味を低下し ていたのは事実であろう.

近松の文章は「鶴が岡」つまり「鎌倉の鶴が岡八幡」 を語り出すための鶴のめでたさを述べる部分である、こ この「土木」は五行にある木, 火, 土, 金, 水のうちの 「土」と「木」にあたる. 白い鶴というものは「内に土 木の気を養い」,つまり「土の黄」「杖青」を内に含 みみながら，外にはその色を出さない白色で自然の精気 豊かな動物だ, と言っているものと解釈できる.したがっ て,「粗野」だとか「教養のない者」とかいう意味は全 くない.ここに出てくる「土木」は, 現在使われている 道路や橋を造る「土木」という言葉とは全く関係のない ものである.この松尾の解釈は全く誤った解釈といえよ う.

\section{7. 明治以後の新しい「土木」が意味するもの}

ここで，新しい「土木」としたのは; 江戸末期まで使 われてきた「普請」という言葉にかわり, 明治維新以後, わが国の近代化と国土建設の目的を持って, 前述の中国 文献や平安, 鎌倉期の「土木」とは異なる意味をもって, 復活させた言葉と定義したからである. また, この言葉
は, 古い「土木」の語義から建築的な要素を取ったもの である.(「建築」という言葉は和製語であり, 幕末に出 版された, 我が国最初の英和辞書である『英和對譯袖珍 鲛書』堀達之助編に “Architectur” の訳語として載つ ている. (10)

この明治以後の新しい「土木」は，「公益の土木」を 目標としており，古い文献にでてくる「土功」あるいは 「普請」の語源に，その意味を見いだすことが出きよう. 現在,「土木」の英訳を “Civil Engineer”としているが, その語源は, 戦争における防御あるいは攻撃を目的とし た構造物の設計・施工を意味する軍事的な言葉である. しかし, これに対して「土功」,「普請」には, 現代の土 木が具備すべき思想につながる語源を持っていると考え られる. そこで，これらについて若干の考察をこころみ た.

まず,「土功」について. 6 章でも述べたように『國語』， 『礼記』など種々の中国文献に使われおり，また，わが 国でも，古い文献から昭和初期まで，「土木」之共に用 いられていたが, 戦後に「土木」あるいは「建設」とい う語に吸収され，見られることが無くなった.

そこで, 『國語』の出典から「土功」を検討する.

[國語・周語］ 単袈公の陳滅亡予言

定王使單襄公聘於宋……中略……

單子歸告王曰, 陳侯不有大各, 國必亡. 王曰, 何故, 對曰, 夫辰角見而雨畢, ……中略……故夏令曰, 九 月除道, 十月成梁. 其時做曰, 収而場功, 侍而畚梮 營室之中, 土功其始, 火之初見, 期於司里. 此先王 所以用財賄, 而廣施徳於天下者也. 今陳國火朝頡矣, 而道路若塞, 野場若棄, 澤不陂障, 川無舟梁, 是癈 先王之教也.

ここで,「故夏令曰」からの解釈として $3 \cdot 1$ と同じく 大野峻（明治書院・新釈漢文大系 67）によると,

夏王朝の法令には『九月には道路を掃除整頓し，十 月には橋を作る』とあります．その時節にしたがっ て出す警告には, 『なんじの農園の収穫を収蔵し, 土を運ぶ畚や梮を準備せよ. 営室星が夕方真南に来 ると，土木工事をはじめ，火星アンタレスが見えは じめると，村長の所へ集合せよ』とあります．これ こそ先王が財源を使わずに，恩徳を広天下に施した 方法です．今陳国は火星アンタレスが朝見えはじめ ても, 道路は雑草で塞がったようですし, 農場は棄 ててしまったようで, 沢は堤防をせず, 川には舟も 橋もありません．これは先王の教えを廃止するもの です.

これから，「土功」つまり土木工事については，収穫 を終えてから行うこと，また，金を使い過ぎるなという ような，為政者が理想とすべき思想が述べられている. さらに,これと同様な意味で『礼記』、『春秋左氏伝』に 
も「土功」という語がしばしば使われている.

つぎに,「普請」について．この語は 6 章の「普請奉行」 にもあるように, 仏教用語で日本独特の言葉である.『広 辞苑』(岩波書店)によると,

[普請]（1）〔仏]禅寺で, 大衆（だいしゅ）を集 めること.また，あまねく大衆に請うて堂塔の建築 などの労役に従事してもらうこと.（2）転じて一 般に, 建築, 土木.

これより，「普請」は禅宗と関係から鎌倉以後の言葉 であることが分かる.ここで，「仏教と土木」について， 忘れてならない人物の第一は奈良時代の僧・行基であろ う. 布教という目的があったにせよ, 行基の民衆の力を 結集して行った土木事業は, 現在の「公益の土木」に通 ずる理想といえよう.このような背景があったからこそ, 始めは単に堂塔の建築などの労役が目的であった「普請」 という仏教語が，一般の「土木」，「建築」を意味する言 葉に変化して行ったのは, ごく自然なことと考えられる. 現在でも「道普請」などの言葉として地方に残っており, 公共または共同の仕事という意味に使われている。この ように「普請」にも「公益の土木」という意味が含まれ ていると解釈できる.

これらより,「土功」,「普請」というすばらしい語源 を受け継いでいる「土木」という言葉を, われわれは後 世に伝える責任があろう。

\section{8. むす び}

中国およびわが国における「土木」の語義の歴史的な 流れを述べてきたが，両国とも「土木」という言葉は現 在の日本語に当てはめるならば「建設」という言葉に近 く, 時代がさかのぼるほど「建築的」な意味が強く感じ られる. 現在われわれが用いている「土木」と同義語と いえるのは「土功」という言葉が最適である.わが国の 江戸時代の文献にも多少は出てくるが，盛んに使われる ようになったのは明治以後である. その他, 土作, 土事 などが土木に近い言葉であり，あるいは治水に関する事 も含んでいる「水土」であろう.また，官職からみると
今の建設省にあたるのは，古くは司空，冬官，將作であ り，後に工部之都水監を一緒にしたものと考えられる. ここで, 都水監について記述してある正史には「土木」 という言葉は全く出てこない. しかし, 中国においては 「河川, 運河」に関する官職が他の土木と独立しており, その重要性が理解できる. わが国においては平安時代末 期から鎌倉時代の文献に「土木」という言葉がでてくる が，その語義は現在の建築という意味合いが強い。その 後は「普請」あるいは「作事」という語が土木を意味す る言葉として使わ机てる. また，前述のように江戸末 期の文献に「普請」と「作事」の説明に「土木」という 言葉が使われており，明治時代になってから突然現れた わけではないことを示している.

本研究を遂行するにあたり種々のご指導を賜った日本 大学 横井博教授（工学部一般教育科 文学博士）に心か ら感謝の意を表します。

\section{参 考 文 献}

1) 佐藤四郎：「土木」是非, 土木学会誌, Vol. 1, 大正 4 年 4 月.

2）石橋絢彦：土木ナル文字ノ詮議, 土木学会誌, Vol.2, 大正 5 年 12 月.

3）松尾春雄：土木技術者の進むべき道, 土木学会誌, Vol. 35, 昭和 25 年 10 月.

4）真田秀吉: 土木という語, 土木学会誌, Vol. 44, 昭和 34 年 6 月.

5) 山内豊聰: 土水, その過去 - 現在 - 将来 九州産業大学 会誌, 第 26 号, 1989.

6) 椎貝博美: 土木工学大系 1 (土木工学概説) 彰国社版, 昭和 57 年 5 月.

7）小川博三：日本土木史概説, 共立出版, 昭 50 年 12 月.

8）成岡昌夫：新大系土木工学, 別巻土木資料百科, 技報堂 出版, 1990 年 6 月.

9）筥瀬一夫 : 方丈記諸注集成, 豊島書房, 昭 44 年 2 月.

10）藤田龍之：“Civil Engineering”の語義および日本語訳 の歴史的経過について, 第 8 回日本土木史研究会論文集, 昭 63 年 6 月.

(1992.5.27 受付)

\section{A STUDY ON THE HISTORICAL CHANGE OF THE MEANING OF THE WORD "DOBOKU”, CIVIL ENGINEERING, IN JAPAN AND CHINA.}

Tatsushi FUJITA

There have been many studies about meaning of the word "DOBOKU" but the historical change on the meaning of the word has not yet been clarified enough. The author consulted not only "SHIKI", "KANJO", and Tetsuji Morohoshi's DAIKANNWAJITEN, but also diaies, essays, and history books in Japan in order to examine the meaning of "DOBOKU" in China and Japan. This paper clarified the change process of the meaning of the word. 